\title{
Key Challenges in Economic Management of Pakistan
}

\author{
Taufiq A. Hussain"
}

\begin{abstract}
This paper points out that GDP growth is fundamentally on track although a little below the expected 7\% target owing to commodity sector weaknesses. The rising trend in unemployment has been reversed over 2002-04. It is expected that longer trend growth over the decade will be over 6\%. However, there are certain macroeconomic imbalances, the current account deficit, the widening savings-investment gap and inflationary pressures, that need to be managed.
\end{abstract}

Pakistan's economy continues to remain on a high-growth trajectory during the current fiscal year, though the real GDP growth rate for the year seems likely to be lower than the 7 percent target. The expectation of the slowdown, relative to the FY06 annual target, owes principally to the (estimated) weakness in the commodity producing sectors of the economy, the impact of which will be partially offset by an anticipated above-target performance of the services sector.

Here, it is important to note that the forecast of deceleration in economic activity during FY06 does not indicate a weakening of future momentum in the trend of economic growth. With substantial investments in the current (and preceding) year, strong domestic demand, buoyant exports, and a relative improvement in FDI (even after excluding privatization receipts), the economy is poised to deliver growth rates in excess of 6 percent through the decade, provided that progress is made towards removing infrastructural bottlenecks, implementing second generation reforms to improve institutions and governance, as well as to further liberalize the economy. Moreover, in the short-run, it will be necessary to address emerging macroeconomic imbalances while these are still small and manageable.

Some of the key macroeconomic imbalances include a rise in the current account deficit, a widening savings-investment gap, and a weakening

\footnotetext{
* Deputy Governor, State Bank of Pakistan
} 
in fiscal indicators (even after adjusting for exceptional earthquake related spending). Also, while inflationary pressures show a very welcome decline, there is a need to ensure that the downward trend persists in the future until the inflation rate comes down significantly.

While inflation has declined from double-digit near term highs in FY05 and is expected to fall to the 8 percent level by end-FY06, it must be recognized that reducing it further is necessary for a host of reasons. These include the need to encourage a rise in savings (by keeping real returns on savings positive), maintaining the purchasing power of incomes, and making exports more competitive (by holding down the cost of production).

It is also important to realize that while the tight monetary posture of the State Bank of Pakistan, (supported by the government's administrative measures) has contributed to a reduction in inflationary pressures, aggregate demand remains strong. During July-February FY06, private sector credit growth was a very substantial 18.1 percent - although weaker than the 25.3 percent rise seen in the comparable period of FY05. And while growth in large scale manufacturing also decelerated, this appears to owe more to factors other than a weakness in demand (e.g. capacity constraints, high-base effects, technical problems, etc.). With this background, a reduction in the rate of inflation and establishment of a clear downward trend will be important priorities for the State Bank, and therefore there is a clear need to continue with monetary tightening.

However, monetary policy will need to be supported by fiscal prudence. While fiscal discipline had been good in recent years, there appears to be trend deterioration in fiscal indicators during FY05 and FY06. The revenue balance is in deficit in both years, and even the primary balance deteriorated significantly in FY06. Going forward, not only does the government need to maintain low fiscal deficits, these should primarily be caused by developmental rather than current expenditure. While development spending generates economic activity to pay off the debt, current spending only adds to the debt burden.

The risk of a further deterioration in fiscal performance also needs to be guarded against. Some key risks include: (1) heavy dependence on import-related taxes, accounting for nearly half of the share in collections (receipts could therefore slow down if, as expected, import growth falls back to historical norms); and (2) dependence on potentially volatile non-tax revenues. Thus, there is a clear need for further tax effort to raise the taxGDP ratio substantially over the next few years. In this context, the reported plan of the Central Board of Revenue (CBR) to seek a one 
percentage point increase in the tax-GDP ratio in the next five years needs to be vigorously implemented. Particular attention needs to be given to the broad-basing of the tax net and improving collections from under-taxed areas of the economy such as agriculture, the service sectors, and the stock market.

Moreover, the mode of financing the fiscal deficit is also important. Borrowing from domestic sources other than State Bank of Pakistan (SBP) simply results in a shift of demand from the private sector to the government, but borrowing from the SBP is more inflationary as it adds to aggregate demand, and therefore financing of the deficit should be through a healthy mix of bank and non-bank borrowing. It should be recalled that the large Rs 178.2 billion increase in budgetary borrowing from the SBP during July-February FY06 was an important driver of monetary expansion in the period. In part, the government's greater reliance on SBP borrowing was driven by weak non-bank receipts, but another contribution was also to the non-issuance of long-term government bonds; almost half of the Rs 31.0 billion net retirement of government borrowing from scheduled banks was due to maturities of these instruments. It is important that the government make fresh Pakistan Investment Bond (PIB) issues to lower dependence on SBP borrowing and to provide a market driven benchmark, which is needed for the development of the corporate bond market.

While low inflation would help provide impetus to growth in the years ahead, a disappointing level of national savings and low investment levels need attention. Specifically, during FY03 and FY04, imports were financed through current account flows. Unfortunately, thereafter imports continued to grow; the growth in non-debt creating foreign exchange inflows no longer kept pace with the growing needs of the economy. This is reflected in the widening current account deficit, resulting in a rising savings-investment gap. This means that in the years ahead the country will be increasingly constrained in its ability to meet the growing consumption and investment needs without generating inflationary pressures and accelerated growth in the country's debt stock, unless there are substantial policy revisions and sustained reforms to meet the challenge of increasing both investment (to increase productive capacity) and savings (to fund Pakistan's investment needs).

One of the current economic issues facing Pakistan today is the sharp deterioration in the current account from a surplus of $1.9 \%$ of GDP in FY04 to a deficit of 1.4 percent of GDP in FY05 that has been fortunately financed by the high capital flows. The persistently higher oil price in the international markets is one of the key reasons for the increase 
in the country's import bills. Interestingly, imports excluding oil are also showing a significant rise during recent years. Despite the easy availability of capital flows it would be desirable to focus on current account sustainability. In this context, the recent increase in the current account deficit though seems sustainable in the short-run, as it reflects the increase in domestic economic activity (which would lead to higher export growth in the future) and also because it is financed by low-cost external sources. But in the longrun, export growth must keep pace with the surge in imports.

Unfortunately, the growth in imports, and therefore the current account deficit, cannot be easily contained. Data suggests that much of the growth in imports comprises either capital goods or inputs for industries. Curtailing these directly would therefore result in a significant fall in economic activities. Moreover, some further growth in imports is inevitable for a developing economy such as Pakistan, particularly as it seeks to address infrastructural shortcomings. The large current account deficit can be sustained in FY06, but hard choices will have to be made in future years, if it continues to persist. The policy options available will revolve around reducing the need for imports by containing the growth in aggregate demand, promoting exports, and attracting non-debt creating flows (e.g. FDI). Less desirable options would be to fund the current account deficits through a mix of privatization receipts and higher debt levels or a significant drawdown of the country's foreign exchange reserves.

Macroeconomic stability and strong economic growth during the last few years has enabled the country to show some progress in social sector development as well. In particular, the rising trend in the rate of unemployment since FY93 has been reversed during FY02-04, despite a faster growth in the labor force. Similarly, the relative improvement in the fiscal position, through sustained efforts in recent years, has allowed the government to substantially increase spending in health, education and other social sector areas. As a result, the positive trends in most of the social indicators have gathered pace during the last few years. However, the social indicators still do not show a satisfactory picture. It is, therefore, important to speed up progress on human development in Pakistan, and the acceleration has to continue consistently to catch up with the backlog and meet the needs of new entrants. In this regard, the sustainability of macroeconomic stability and maintaining the current growth momentum remain essential. Moreover, the government should significantly augment development spending, increase the efficiency of expenditures, and foster better partnerships with the private sector to improve the delivery of services. The government's efforts could be complemented by increased 
access to financial services of the populace (especially to the SME and microfinance sectors, until recently neglected).

\section{Future Outlook of Pakistan's Economy}

Current SBP forecasts indicate that real GDP growth will be in the range of $6.3-6.8$ percent during FY06. Headline inflation (in terms of the CPI) is projected to be in the $7.7-8.3$ percent range during FY06. While the deceleration is certainly welcome, the downtrend in inflation needs to be firmly established to maintain macroeconomic stability. SBP will therefore continue to retain a tight monetary stance. However, it is important to note that monetary policy alone will not be able to contain all the rise in inflationary pressures. In particular, there is an urgent need for the government to supplement its very laudable supply-side measures with policies to address market structure problems. Specifically, anecdotal evidence clearly suggests that in recent years, speculative hoarding and collusive price setting have been significant contributors to domestic inflationary pressures in markets for many key commodities. Such pressures respond more to legal and administrative measures, and are less sensitive to monetary tightening.

In contrast to the welcome decline in inflation, the external balance has deteriorated significantly in FY06. Although remittances are expected to show reasonable growth and exports are likely to remain strong, the current account deficit is expected to increase to 4.7 percent of GDP by end-FY06. While this is not low, it is quite sustainable in the short run. In the longer run, however, large current account deficits cannot be sustained, as these would initiate a vicious circle of debt creation, exchange rate depreciation, and inflation.

Let me conclude by saying that given the fast growing trends of aggressive globalization and increasing regional competition, Pakistan needs to continue with sound macroeconomic policies, which are the lynchpin of restoring both domestic and foreign investor confidence. Macroeconomic management today is complicated by Pakistan's need to continue growing which does require it to stretch its resource base, and the country will have to carefully gauge its priorities in seeking to meet these challenges. 
Annexure-I

Major Economic Indicators

\begin{tabular}{lcc}
\hline FY05 & \multicolumn{2}{c}{ FY06 } \\
\hline & $\begin{array}{c}\text { Original } \\
\text { targets }\end{array}$ & $\begin{array}{c}\text { SBP } \\
\text { projection }\end{array}$ \\
\hline
\end{tabular}

Growth rates (percent)

$\begin{array}{lccc}\text { GDP } & 8.4 & 7.0 & 6.3-6.8 \\ \text { Inflation } & 9.3 & 8.0 & 7.7-8.3 \\ \text { Monetary assets (M2) } & 19.3 & 12.8 & 14.3\end{array}$

\section{Billion USS}

Exports (fob-Customs record)

14.4

16.9

Imports (cif-Customs record)

20.6

$-$

28.8

Workers' remittances

4.2

4.0

4.3

Percent of GDP

Fiscal balance

$-3.3$

$-3.8$

$-4.5$

Current account balance

$-1.4$

$-2.2$

$-4.7$

State Bank of Pakistan 